\title{
TRAJNOSTNI PROSTORSKI RAZVOJ IN NOVEJŠI PROCESI V PROSTORSKEM RAZVOJU LJUBLJANE
}

Dejan Rebernik

Oddelek za geografijo Filozofske fakultete Univerze v Ljubljani, Aškerčeva 2,

SI - 1000 Ljubljana, Slovenija

e-mail: dejan.rebernik@guest.arnes.si

Izvirni znanstveni članek

COBISS 1.01

\section{Izvleček}

Osnovni cilj prispevka je evidentiranje, analiza in vrednotenje temeljnih značilnosti in najnovejših procesov $\mathrm{v}$ prostorskem razvoju na primeru mesta Ljubljana $\mathrm{z}$ vidika trajnostnega prostorskega razvoja mest. V prvem delu so navedena temeljna teoretska izhodišča in koncepti trajnostnega prostorskega razvoja mest ter usmeritve, cilji in ukrepi na področju prostorskega razvoja mest, ki jih predvidevajo dokumenti slovenske prostorske politike. Podrobneje je predstavljeno stanje, trendi in procesi $\mathrm{v}$ prostorskem razvoju Ljubljane po posameznih izbranih področjih: notranji razvoj mesta, degradirana urbana območja, območja razpršene poselitve, funkcijska preobrazba in racionalna raba zemljišč ter stanovanjska območja.

Ključne besede: mesta, urbanizacija, trajnostni prostorski razvoj, degradirana urbana območja, revitalizacija, Ljubljana.

\section{SUSTAINABLE SPATIAL DEVELOPMENT AND NEW TRENDS IN URBAN DEVELOPMENT OF LJUBLJANA}

\begin{abstract}
The main goal of the paper is to identify, analyse and evaluate the basic processes in spatial development in Ljubljana. In the first part of the paper the main theoretical and planning concepts of sustainable urban development as well as goals and aims of Slovene spatial policy regarding urban development are presented. Characteristics and processes of recent urban development of Ljubljana are presented in five themes: inner urban development, derelict urban areas, areas of dispersed urbanisation, functional transformation and mixed urban land use and residential areas.
\end{abstract}

Key words: cities, urbanisation, sustainable urban development, derelict urban areas, evitalisation, Ljubljana. 


\section{UVOD}

V Strategiji prostorskega razvoja Slovenije (2004) so glede prostorskega razvoja mest in širših mestnih območij v skladu z izbranim »vzdržnim prostorskim razvojem«, kot osnovni cilji in usmeritve poudarjeni usmerjevanje poselitve v poselitvena območja urbanih naselij ob ohranjanju kakovosti naravnega in bivalnega okolja, »notranji razvoj naselij«, ki se zagotavlja z izkoriščanjem prostih ali neprimerno izkoriščenih zemljišč znotraj naselij in prenova naselij, s katero se ob upoštevanju varovanja kulturne dediščine izboljšuje kakovost bivalnega okolja in sanira degradirana urbana območja. Notranji razvoj naj bi imel prednost pred širjenjem naselij na nova območja, ki je dopustno le v primeru, če površine znotraj naselja ne zagotavljajo možnosti za ustrezen razvoj v skladu z razvojnimi potenciali določenega mesta. Za doseganje tako zastavljenih ciljev na področju poselitve Strategija prostorskega razvoja Slovenije predvideva izvajanje ustreznih ukrepov, zlasti aktivno zemljiško politiko.

Slovenska mesta doživljajo v času gospodarske tranzicije, globalizacije in evropske integracije temeljito gospodarsko, socialno, funkcijsko in prostorsko preobrazbo. Kljub jasno zastavljenim ciljem in usmeritvam $\mathrm{v}$ nacionalnih in evropskih strateških prostorskih dokumentih se v Sloveniji nadaljujejo izrazito (ne)trajnostne oblike in procesi prostorskega razvoja mest in širših mestnih območij. Učinki prehoda v tržno gospodarstvo so še zlasti vidni $\mathrm{v}$ procesih preobrazbe funkcijske zgradbe in rabe tal $\mathrm{v}$ mestih in $\mathrm{v}$ povečevanju prostorske socialne segregacije prebivalstva. Funkcijska preobrazba mest tako postavlja nova razmerja in odnose med posameznimi deli mesta, kot so na primer mestno središče in stanovanjska, oskrbno - storitvena, proizvodnja in rekreacijska območja. S prostorskim razvojem in preobrazbo se postopno spreminja tudi prometna dostopnost, vrednost in intenzivnost izrabe mestnih zemljišč. Posledično prihaja do razvrednotenja in degradacije posameznih urbanih območij. Pomanjkanje in visoke cene zazidljivih zemljišč, poslabšana prometna dostopnost in zniževanje kvalitete bivalnega okolja v osrednjih delih mest povzročajo decentralizacijo prebivalstva in dejavnosti (trgovina, storitve, poslovne dejavnosti) v širša mestna območja. $\mathrm{K}$ temu prispevajo tudi obremenitve okolja, povezane zlasti z zgoščenim prometom, ki vplivajo na poslabšane bivalne razmere (zmanjšana kakovost zraka, hrup) v osrednjih delih mest. Neposredna posledica takšnih procesov je prostorska širitev mest v obliki razpršene in (ne)načrtovane urbanizacije širših mestnih območij (»urban sprawl«) in decentralizacija prebivalstva ter zaposlitve.

Med vsemi slovenskimi mesti doživlja Ljubljana najbolj intenziven gospodarski razvoj, ki se kaže zlasti v hitrem naraščanju števila delovnih mest v mestu in celotni urbani regiji. Število delovnih mest v Mestni občini Ljubljana se je tako od 139.000 leta 1995 povečalo na 177.000 leta 2005 (Statistični letopis Ljubljana, 2006). Koncentracija delovnih mest in širitev oskrbnih ter storitvenih dejavnosti povzroča povečevanje obsega in intenzivnosti dnevne migracije in prometnih tokov. Kljub nadaljevanju upadanja števila prebivalstva v Ljubljani (med leti 1995 in 2005 za približno 10.000 prebivalcev) je zaradi sprememb v demografski strukturi in sestavi gospodinjstev ter višanja stanovanjskega standarda značilno tudi veliko povpraševanje po novih stanovanjih. Vse to pripeva k povečevanju povpraševanja po komunalno opremljenih zazidljivih zemljiščih v mestu za stanovanjsko gradnjo in za širitev trgovskih, poslovnih, storitvenih in proizvodnih dejavnosti, predvsem s strani zaseb- 
nega kapitala. Zaradi zadrževanja zazidljivih zemljišč s strani zemljiških špekulatorjev, neurejenih lastniških razmerij ter neskladja med plansko določeno namensko rabo in interesi ter potrebami investitorjev prihaja $\mathrm{v}$ Ljubljani do velikega pomanjkanja in posledično zelo visokih cen zemljišč. Ob vsem tem je veljavni prostorski akt za območje Mestne občine Ljubljana (Dolgoročni plan občin in mesta Ljubljane, 1986 - 2000), ki je nastal v osemdesetih letih v razmerah družbene lastnine, za današnje razmere popolnoma neprimeren in predstavlja veliko oviro za učinkovito urbanistično planiranje v Ljubljani. Takojšna priprava in sprejem nove generacije prostorskih aktov (Strategija prostorskega razvoja, Prostorski red občine in občinski lokacijski načrti) je v primeru Ljubljane zato še posebno nujna.

Osnovni cilj prispevka je evidentiranje, analiza in vrednotenje temeljnih značilnosti in procesov v prostorskem razvoju na primeru mesta Ljubljana. V prvem delu prispevka bodo na osnovi pregleda literature in nekaterih evropskih dokumentov s področja prostorskega razvoja navedena temeljna teoretska izhodišča in koncepti trajnostnega prostorskega razvoja mest. V nadaljevanju bodo predstavljene usmeritve, cilji in ukrepi na področju prostorskega razvoja mest, ki jih predvidevajo Strategija prostorskega razvoja Slovenije, Strategija razvoja Slovenije in Prostorski red Slovenije. Predstavljene bodo tudi osnovne usmeritve prostorskega razvoja Ljubljane v Prostorski zasnovi Mestne občine Ljubljane. V osrednjem delu prispevka bodo na osnovi dosegljivih podatkov, pregleda novejših analiz in lastnega kartiranja evidentirani osnovi procesi v prostorskem razvoju mesta. Prostorski procesi v Ljubljani bodo umeščeni v okvir širših pravnih, gospodarskih in socialnih razmer ter ovrednoteni z vidika trajnostnega prostorskega razvoja mest. Podrobneje bo predstavljeno stanje, trendi in procesi v prostorskem razvoju mesta po posameznih izbranih področjih: notranji razvoj mesta, degradirana urbana območja, območja razpršene poselitve, funkcijska preobrazba in racionalna raba zemljišč ter stanovanjska območja. Ugotovljeni procesi v prostorskem razvoju mesta bodo soočeni z usmeritvami in cilji slovenske in mestne prostorske politike. Podana bodo temeljna neskladja oziroma konflikti v prostorskem razvoju Ljubljane. Na osnovi tega bodo podani možni ukrepi za učinkovitejšo udejanjanje ciljev trajnostnega prostorskega razvoja v Ljubljani.

\section{TRAJNOSTNI PROSTORSKI RAZVOJ MEST}

$\mathrm{V}$ drugi polovici 20. stoletja $\mathrm{v}$ gospodarsko najbolj razvitih državah nastopi nova, tako imenovana terciarna ali post-industrijska faza urbanizacije. Glavni impulz urbanizacije postane terciarizacija družbe in gospodarstva. Ob visokem standardu, visoki prostorski mobilnosti prebivalstva in drugačnih vrednotah se uveljavijo novi procesi preobrazbe mest in urbanih območij: metropolizacija, suburbanizacija, counterurbanizacija, exurbanizacija, reurbanizacija itd. Skupna značilnost vseh teh procesov je dekoncentracija in decentralizacija mestnega prebivalstva in urbanih dejavnosti. V prvi fazi prihaja do razseljevanja prebivalstva iz osrednjega dela mesta na mestno obrobje oziroma v območje suburbanizacije. V naslednji fazi se prebivalstvo razseljuje $v$ vedno bolj oddaljena območja v okolici mesta. V terciarni fazi urbanizacije mesta tako izgubljajo prebivalstvo na račun rasti mestnega obrobja oziroma območja suburbanizacije, v zadnji fazi prebivalstvo izgubljajo celotne urbane regije na račun naraščanja prebivalstva na podeželju. Razseljevanju prebivalstva sledi dekoncentracija 
sekundarnih in terciarnih dejavnosti. Oblikujejo se sekundarna trgovska in poslovna središča oziroma robna mesta. Na ta način se oblikujejo sodobna metropolitanska območja oziroma urbane regije, za katere je značilna disperzna, policentrična in mrežna struktura. Močno se okrepijo dnevne migracije delovne sile in prostorska mobilnost prebivalstva znotraj urbane regije in v širšem vplivnem območju mest. Za post- industrijsko urbanizacijo je torej značilna fragmentacija urbanih struktur (Pacione, 2001, str. 61).

Vsi ti dejavniki so povzročili izjemno prostorsko širitev območij poselitve v obliki redke, med seboj nesklenjene urbanizacije. $Z$ razpršenim urbanim razvojem se zato povezujejo številni negativni okoljski, socialni in prostorski učinki. Med okoljskimi učinki se izpostavlja predvsem izgubo kmetijskih površin, gozdov in drugih oblik naravnega okolja (npr. mokrišča), kar ima številne negativne gospodarske in okoljske posledice. Močno se poudarja negativne učinke povečanega prometa, ki je neposredno povezan $\mathrm{z}$ razpršeno urbanizacijo: onesnaževanje zraka, povečana poraba energije, poraba površin za prometnice, izguba časa in gospodarska škoda zaradi prometnih zastojev. Med socialnimi učinki se navaja »izgubo prostorske identitete « posameznih urbanih in ruralnih območij, povečano socialno segregacijo $\mathrm{s}$ koncentracijo nižjih socialnih slojev $\mathrm{v}$ mestnih središčih ter pospešeno propadanje mestnih središč in starejših predmestij. Poglavitni negativni prostorski učinki pa so neracionalna raba prostora in neracionalna raba že obstoječe ter visoki stroški izgradnje nove infrastrukture. Urban sprawl je torej oblika izrazito »netrajnostnega« prostorskega razvoja $\mathrm{z}$ visokimi »družbenimi« stroški.

Kot rešitev in odgovor na takšen prostorski razvoj se je v ZDA oblikoval koncept smart growth. Gre za cilje, načela in ukrepe prostorskega planiranja, ki naj preprečijo in omejijo negativne posledice razpršene urbanizacije. Smart growth lahko definiramo kot premišljeno in učinkovito planiranje, ki usmerja razvoj v obstoječa urbanizirana območja, omogoča razvoj javnega prevoza in varuje kmetijske površine ter naravno okolje. Bistveni poudarek koncepta smart growth je tudi obnova in revitalizacija osrednjih ter starejših delov mesta.

Oblika urbane poselitve je temeljni strateški dejavnik, ki določa mestno sonaravnost. Vpliva na vzorce privatnega in javnega prometa in s tem na porabo goriva in emisije, stopnjo pretvorbe kmetijskih zemljišč $\mathrm{v}$ urbane površine in posledično na izgubo habitatov za rastline in živali. Prednostni pristop k sonaravnemu vzorcu naselij naj bi imel dve stopnji: učinkovitejša raba zemljišč v obstoječih mestnih območjih, zlasti sanacija opuščenih zemljišč in minimizacija rabe energije za potovanja z načrtovanjem mešane rabe mestnih zemljišč (Plut, 2006, str. 165). Evropska komisija za okoljsko urbano politiko (Environmental Policies..., 1990) sodi, da so sklenjena mesta energetsko najbolj primerna oblika bivanja, ker je poraba energije za promet najmanjša, obenem pa je največ možnosti za učinkovito organiziranje javnega prometa (Plut, 2006, str. 168). Gosto, kompaktno mesto, ki varčuje s prostorom in rešuje probleme prevoza, postaja urbanistični ideal (Petršin, 2000). Koncept kompaktnega, zelo gosto naseljenega mesta $\mathrm{z}$ delno mešano rabo mestnega prostora naj bi zagotavljal energetsko učinkovito urbanega razvoja, ki zmanjšuje potovalne razdalje in omogoča zelo učinkovit javni prevoz (Pacione, 2001, str. 591). Kompaktno mesto je postalo vodilni princip sonaravnega urbanega razvoja, vendar nekateri raziskovalci upravičeno opozarjajo na določene omejitve z vidika kakovosti življenja, rabe zemljišč in njihove (visoke) cene (Banister in drugi, 2000, str. 36). Zato obstajajo tudi drugačna gledanja, delno zasnovana na tako imenovani globoki ekologiji 
in močni sonaravnosti, ki predlagajo skrajno in večplastno decentralizacijo z nizko gostoto poselitve, ki naj bi omogočila trajno rabo lokalnih energetskih virov in domačo pridelavo hrane. Nekateri raziskovalci tudi opozarjajo na določene omejitve z vidika kakovosti življenja in rabe zemljišč v kompaktnih mestih (Plut, 2001, str. 165). Pogačnik tako zagovarja mrežno - mozaični model kot optimalni poselitveni vzorec za Slovenijo. To je optimalna »mešanica« rabe tal, vozlišč in aktivnosti na mreži komunikacij in infrastrukture (Pogačnik, 2000, str. 175). Mesta prihodnosti se bodo tako po mnenju avtorja fizično razblinila v obsežne ruralnourbane zgostitvene regije. Definicijo mesta naj bi zamenjala definicija mestnega teritorija oziroma mestne regije.

Z vidika sonaravnosti je po mnenju Pluta (Plut, 2006, str. 161, povzeto po Kemp, 2004) umestna tipologija naslednjih faz in oblik urbanega razvoja :

a. Strnjeno, zgoščeno (kompaktno) mesto: obkroženo z mesti in vasmi različne velikosti, omejeno prometno omrežje različne kakovosti, visoka stopnja samozadostnosti mesta.

b. Zgoščeno mesto s satelitskimi naselji in zelenimi območji: okrepljen razvoj satelitskih mest, izboljšanje in večja gostota prometnega omrežja, zaščita podeželja z zelenimi območji.

c. Urbani razvoj v smeri prometnih koridorjev (trakov): zgostitev pozidave vzdolž glavnih cestnih povezav mesta in satelitskih skupnosti, kakovostna cestna mreža, obremenjevanje podeželja vzdolž glavnih vzdolž glavnih cestnih povezav.

d. Razraščanje mesta (»urban sprawl«): velika gostota cestnega omrežja, razvoj območij bivanja in storitev v celoti nadomesti naravno okolje, glavno mesto in satelitska naselja se zlivajo v metropolitansko območje.

\section{USMERITVE IN CILII V PROSTORSKEM RAZVOJU MEST V SLOVENIJI IN LJUBLJANI}

Strategija prostorskega razvoja Slovenije (2004), kot temeljni državni dokument o usmerjanju razvoja v prostoru podaja prioritete, cilje, usmeritve in zasnovo urejanja prostora na področju poselitve. V okviru prioritet prostorskega razvoja so posebno izpostavljena vitalna in urejena mesta in usklajen razvoj širših mestnih območij. Strategija naselja razvršča v več tipov (velika, srednja in mala mesta, druga urbana in podeželska naselja). Nova poselitev se usmerja predvsem v poselitvena območja urbanih naselij. Naselja se načrtuje v skladu z naravnimi in drugimi omejitvami ter tako, da je zagotovljena smotrna raba energije.

Notranji razvoj naselij, kipomeni zapolnjevanjein zgoščanja oziroma intenzivnejšorabo ekstenzivno izrabljenih ali praznih zemljišč, ima prednost pred širjenjem na nova področja. Na ta način se zmanjšuje pritisk na nova zemljišča na obrobjih mest (Obrazložitev in utemeljitev, Strategija prostorskega razvoja Slovenije, str. 42). Zgoščevanje in notranji razvoj mest pomeni tudi priložnost za bolj učinkovito in racionalno zagotavljanje dostopnosti do oskrbe, storitev in delovnih mest ter organizacijo javnega prometa. Strategija ugotavlja, da zemljišča, ki so v prostorskih planih občin, namenjena gradnji, v večini primerov zadoščajo potrebam razvoja določenega naselja, da pa se zaradi zadrževanja parcel vedno znova pojavljajo zahteve po širitvi naselij. Potrebna je torej aktivna zemljiška politika, tudi z uveljavitvijo višjih davčnih stopenj za ekstenzivno izrabljena zemljišča. 
Prenova naselij, ob upoštevanju varovanja kulturne dediščine, predstavlja prednostno razvojno usmeritev. Prenova naselij zagotavlja izboljšanje kakovosti bivalnega okolja in sanacijo degradiranih urbanih območij. Še posebno je poudarjena prenova degradiranih urbanih območij (območja opuščene rabe, zlasti opuščena vojaška, industrijska, transportna in stanovanjska območja), ki v večino slovenskih mest zasedajo velike površine in predstavljajo velik razvojni potencial mest.

Za ustrezen razvoj mest in naselij ter še zlasti za konkurenčnost nacionalnih urbanih središč bo potrebno zagotoviti površine za širitev naselij. Zaradi koncentracije prebivalstva in dejavnosti v pomembnejših zaposlitvenih središčih se bo po oceni, ki je podana v Strategiji prostorskega razvoja Slovenije, potreba po novih stanovanjih povečala za $9 \%$ oziroma približno 42.000 stanovanj. Ob upoštevanju potreb po širitvi ostalih urbanih površin se bo potreba po novih urbanih površinah $\mathrm{v}$ nacionalnih, regionalnih in medobčinskih središčih povečala za 2419 ha (Obrazložitev in utemeljitev, Strategija prostorskega razvoja Slovenije, str. 44).

Gradnja zunaj poselitvenih območij je usmerjena prvenstveno v sanacijo razpršene poselitve, ki je obravnavana kot negativen pojav. Razpršena gradnja je sporna predvsem zaradi nizke gostote poselitve, zlasti na obrobju mest in v obmestnih naseljih. Ne omogoča racionalne komunalne opreme in rabe energije. Razpršeno gradnjo v predmestjih in obmestnih naseljih se sanira z zgoščevanjem stanovanj in urbanih dejavnosti. Zgošča in zaokroža se predvsem tisto razpršeno gradnjo, ki ima možnosti za ustrezno prometno in komunalno ureditev, oskrbo $\mathrm{z}$ urbanimi dejavnostmi in navezavo na javni promet.

Za doseganje trajnostnega prostorskega razvoja mest in drugih naselij je bistvenega pomena racionalna raba zemljišč in objektov $\mathbf{v}$ naselij. Pri prostorskem razporejanju zemljišč po namenski rabi in dejavnosti se stremi k takšnemu prepletu funkcij, ki so medsebojno združljive in ne motijo druga druge. Uveljavlja se nova organizacija v mest, kjer se funkcije prepletajo. Preprečuje se izrazito monofunkcionalnost posameznih delov naselij z uvajanjem raznovrstnosti dejavnosti ter mešanjem funkcij bivanja in dela. Uvaja se torej »mešana raba«, ki zmanjšuje transportne razdalje, povezane $\mathrm{z}$ dnevnimi migracijami na delovno mesto (Obrazložitev in utemeljitev, Strategija prostorskega razvoja Slovenije, str. 47).

$\mathrm{V}$ urbanih naseljih se na podlagi ustreznih raziskav načrtuje in zagotavlja komunalno opremljene površine za stanovanjsko gradnjo in prenovo obstoječih stanovanjskih območij. $\mathrm{Na}$ novih območjih se izvaja prvenstveno organizirana stanovanjska gradnja s primerno gostoto in tipom pozidave. Prosto stoječa enostanovanjska hiša na relativno velikih parcelah (povprečno $800 \mathrm{~m} 2 \mathrm{v}$ mestih in $1000 \mathrm{~m}^{2} \mathrm{v}$ obmestnih naseljih) je ekonomsko in ekološko neprimerna oblika zazidave, ker zahteva visoke stroške komunalnega opremljanja in neracionalno rabo zemljišč. Za širitev stanovanjske gradnje je primerna zlasti gosta nizka zazidava (na primer vrstne hiše), ki ohranja vse prednosti enodružinske hiše, pri čemer je izkoristek zemljišča bistveno boljši. Tipe zazidave se nujno uskladi z obstoječo zazidavo.

Območja centralnih dejavnosti(oskrbne in poslovne dejavnosti, družbena infrastruktura in stanovanja) so locirana v območjih dobre dostopnosti, zlasti v mestnih središčih. V naselju se oblikuje atraktivna in enakomerno razmeščena in dostopna območja centralnih dejavnosti, s čimer se preseže razdeljenost mesta na kraj bivanja in kraj dela (Obrazložitev in utemeljitev, Strategija prostorskega razvoja Slovenije, str. 48). Nova nakupovalna in druga specializirana območja se lahko locirajo na obrobju naselij z dobro prometno dostopnostjo samo ob pogoju, 
da dopolnjujejo funkcije naselja in ne ogrožajo vitalnosti in privlačnost mestnega središča.

V okviru načrtovanja območji proizvodnih dejavnosti se v urbanih naseljih zagotavlja zadostno ponudbo površin za industrijo, proizvodnjo obrt in druge oblike podjetništva, s čimer se ustvarjajo pogoji za večjo konkurenčnost in pritegnitev investitorjev za nova delovna mesta. Pri razvoju gospodarskih con se upošteva tudi prostorske kriterije, pri izbiri lokacije se preveri možnost prenove in sanacije opuščenih industrijskih, komunalnih, prometnih in podobnih območij.

Zelene površine so pomembna sestavina urjenega naselja; prispevajo $\mathrm{h}$ kvaliteti bivalnega okolja, omogočajo zadovoljevanje socialnih funkcij in prispevajo k strukturni in oblikovni podobi naselja (Obrazložitev in utemeljitev, Strategija prostorskega razvoja Slovenije, str. 49).V naseljih se zagotavlja zadostne zelene površine glede na obsežnost območja in število prebivalcev. Oblikuje se zeleni sistem naselja, v katerega se vključi zelene površine naselja, vodni in obvodni prostor ter kmetijske in gozdne površine.

Pri načrtovanju razvoja prometnih površin se podpira širjenje centralnih peš površin in razvoj kolesarskega mestnega omrežja ter razvoj javnega potniškega prometa. Potrebni so ukrepi celovite prostorske politike, ki naj zagotavljajo učinkovitost prometnega sistema in dobro dostopnost vseh delov naselja. Mesta so preobremenjena z osebnim prometom, zato je treba zlasti $v$ njihovih središčih omejevati in zmanjševati osebni avtomobilski promet. Zmanjšuje se ga z obvozi in tangentnimi prometnicami, javnimi garažami in parkirišči na obodu, z razvojem sistema »parkiraj in se pelji«, časovni omejevanjem parkiranja, s ceno parkiranja, z razvojem javnega peš in kolesarskega prometa. (Obrazložitev in utemeljitev, Strategija prostorskega razvoja Slovenije, str. 50). Podpira se razvoj javnega potniškega prometa (železnica, tramvaj, avtobus).

Komunalno opremljanje zemljišč je gradnja komunalne infrastrukture, ki je potrebna da se lahko prostorske ureditve ali objekti izvedejo. Komunalno opremljanje zemljišč ima tvorno funkcijo pri razvoju dejavnosti v prostoru, saj je predpogoj, da objekte lahko začnemo graditi. Na ta način komunalna oprema zemljišč vpliva na prostorsko razporeditev dejavnosti in prostorski razvoj naselij. Prednost imajo vlaganja v obnovo zapuščenih komunalno opremljenih zemljišč.

Pri načrtovanju in urejanju mest in drugih naselij se stremi k urejenemu in prostorsko uravnoteženemu in oblikovno skladnemu razvoju posameznega naselja tako, da se zagotavlja arhitekturno prepoznavnost na ravni celotnega naselja in na ravni posamezne funkcionalne enote ali dela naselja. Varuje se podobo, merilo ali krajinski okvir, sanira vidno degradirane prostore in ustvarja novo arhitekturno prepoznavnost v sožitju z obstoječimi vrednotami prostora. Z načrtno prenovo se ohranja zgodovinska naselja oziroma njihove dele, zlasti tiste, ki so naselbinska dediščina.

Prostorska zasnova Mestne občine Ljubljana predstavlja prvo fazo priprave nove generacije prostorskih aktov (po veljavni zakonodaji Strategija prostorskega razvoja občine in prostorski red občine). Gre za konceptualni, dolgoročno naravnan dokument, katerega osnovni namen je dati izhodišča in usmeritve za nadaljnjo pripravo prostorskega plana (Zasnova prostorskega razvoja, 2001). V prostorski zasnovi so tako podane vodilne usmerite $\mathrm{v}$ urejanju prostora, cilji usmerjanja prostorskega razvoja in zasnova organizacije prostora po posameznih področjih. $\mathrm{V}$ uvodu je poudarjena nujnost izdelave in sprejetja novih in novim 
razmeram prilagojenih prostorskih dokumentov in ustreznih inštrumentov, ki bodo omogočali učinkovito prostorsko načrtovanje in usmerjanje razvoja na območju mesta Ljubljana. Med cilji prostorskega razvoja mesta so izpostavljeni zlasti :

- $\quad$ dopolnjujoče prepletanje dejavnosti«: mozaična razmestitev dejavnosti v prostoru in mešana raba tal

- " "prestrukturiranje prometa«: večja učinkovitosti in uporaba javnega potniškega prometa

- $\quad$ zdravo in varno mesto«: upoštevanje načel sonaravnega razvoja

- $\quad$ »zgoščevanje mesta«: notranji razvoj mesta, sanacija degradiranih urbanih območij

- $\quad$ "prenova in umirjanje«: preprečevanje razpršene gradnje

- "povezava zelenih površin v sistem«

V zasnovi organizacije prostora je poudarjen morfološki razvoj mesta v krakih ob glavnih mestnih vpadnicah in zaščita vmesnih zelenih krakov, uvajanje kategorije »mešane rabe tal« s prepletanjem med seboj kompatibilnih dejavnosti, razvoj zmogljivega in visoko kakovostnega javnega prometa, s poudarkom na mestni železnici in dosledno varovanje območij poudarjenega varstva.

\section{PROSTORSKI RAZVOJ LJUBLJANE PO LETU I 995}

$\mathrm{V}$ osrednjem poglavju prispevka želimo prikazati stanje, trende in poglavitne procese v prostorskem razvoju in preobrazbi Ljubljane v zadnjih desetih letih. Analiza prostorskega razvoja in preobrazbe mesta je razdeljena v pet vsebinskih sklopov :

1. Notranji razvoj mesta

2. Degradirana urbana območja

3. Območja razpršene poselitve

4. Funkcijska preobrazba in racionalna raba zemljišč

5. Stanovanjska območja

Znotraj vsakega vsebinskega sklopa je predstavljena analiza stanja, trendov in najnovejših procesov in tudi njihovo vrednotenje $\mathrm{z}$ vidika trajnostnega prostorskega razvoja.

\section{I Notranji razvoj mesta}

Prostorski razvoj v naselij v Sloveniji je večinoma ekstenziven, naselja se pretežno širijo na nepozidane površine $\mathrm{v}$ okolico, najpogosteje $\mathrm{v}$ obliki razpršene poselitve, kar velja tudi za Ljubljansko urbano regijo. Kljub temu je po letu $1995 \mathrm{z}$ razmahom zasebne stanovanjske gradnje in razvojem poslovnih, oskrbnih in storitvenih dejavnosti opazno povečanje izrabe prostih zemljišč znotraj Ljubljane. Zasebni kapital je s svojimi investicijami postal poglavitni akter (pre)oblikovanja mesta in njegovih grajenih struktur. V Ljubljani zasebni kapital intenzivno investira $v$ stanovanjsko gradnjo, trgovska in storitvena središča ter poslovne cone. Pri tem sta se v zadnjih letih vzpostavila dva vzorca prostorskega razvoja mest. Na eni strani se nadaljuje (ne)načrtovano širjenje poselitvenih površin v širšem mestnem območju, zlasti 
v obliki razpršene gradnje enodružinskih hiš, skupin večdružinskih hiš, nakupovalnih središč in gospodarskih con. Na drugi strani pa se krepi tudi »notranji razvoj mesta« v obliki gradnje in zgoščevanja urbanih struktur znotraj strnjenega urbanega območja, predvsem na obrobju mestnega središča, v obstoječih stanovanjskih, proizvodnih in oskrbno-storitvenih območjih ter v degradiranih urbanih območij. Praviloma gre za posamezne večstanovanjske zgradbe, redkeje tudi za manjše stanovanjske soseske oziroma za objekta in površine namenjene poslovnim ali storitvenim dejavnostim. Na ta način prihaja do zgoščevanja urbanih struktur in izrabe prostih površin znotraj mesta, kar je ena izmed temeljnih usmeritev prostorskega razvoja mest v strateških dokumentih slovenskega prostorskega razvoja, toda ta »notranji razvoj« je $\mathrm{v}$ celoti prepuščen zasebni iniciativi, kar se pogosto odraža v neprimernih, neprilagojenih in neusklajenih posegih v prostor, ki zmanjšujejo kvaliteto bivalnega okolja, povzročajo nove prometne tokove in dodatno degradacijo urbanih območij. Gradnja na prostih parcelah znotraj mesta je večinoma »točkovna«, najpogosteje v obliki posameznih večstanovanjskih hiš (»vila blok «). Gradnja pogosto ni usklajena z morfološkimi značilnostmi območja (na primer gradnja dvo- ali tro- nadstropnih stanovanjskih blokov v območju enodružinskih hiš). Izraba parcele je pogosto previsoka, kar poslabšuje kvaliteto bivalnega okolja oziroma preobremenjuje prometno omrežje v določenem delu mesta. Ob tem opozarjamo na pomanjkanje ustreznih urbanističnih normativov in mejnih vrednosti v prostorski zakonodaji in dokumentih.

Slika 1: Notranji razvoj in zgoščevanje stanovanjskih območij- nove večstanovanjske zgradbe v soseski enodružinskih hiš Galjevica

Figure 1: Inner development and increased density in residential areas - new apartment buildings in neighbourhoods of one family houses

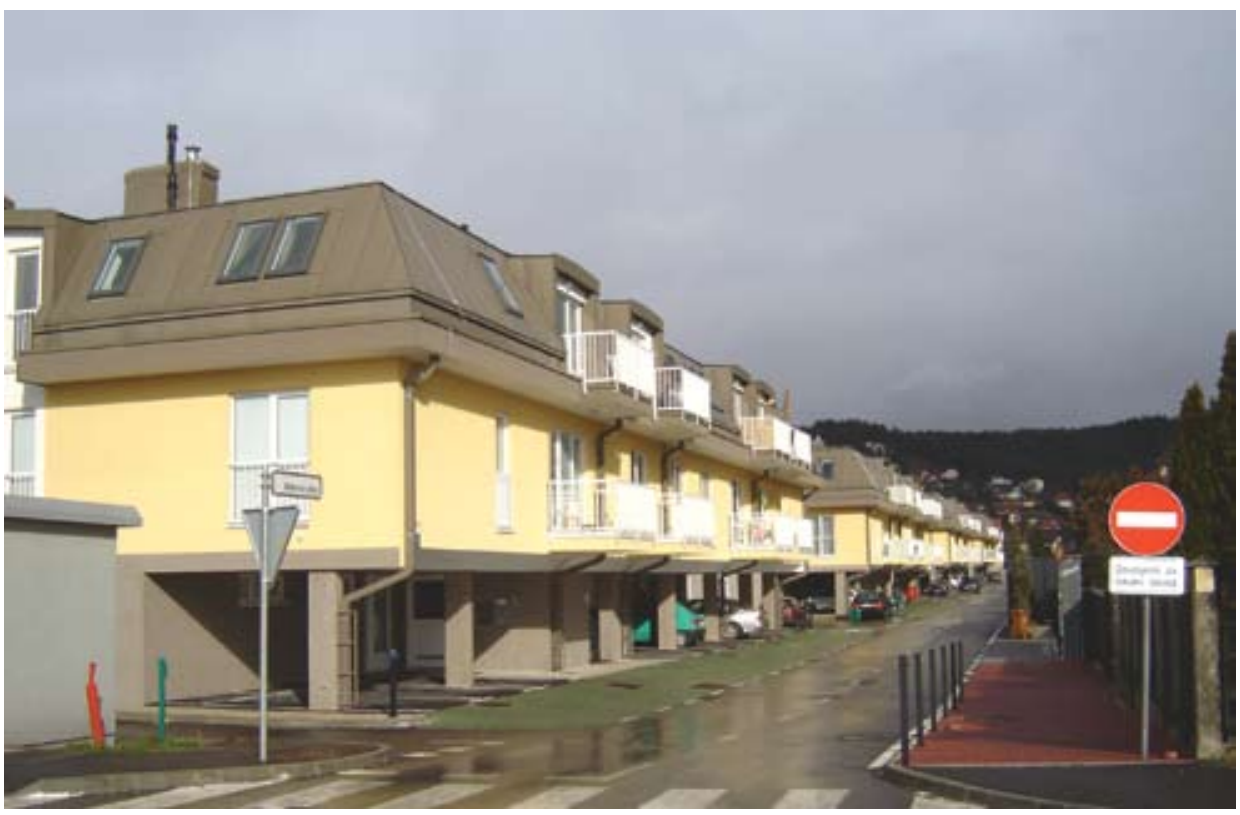




\subsection{Degradirana urbana območja}

Degradirana urbana območja« so nekakšen stranski produkt procesov ekonomske, funkcijske, socialne in prostorske preobrazbe mest. Degradacija urbanih območij je torej »začasno« stanje, ki spremlja preobrazbo vsakega urbanega sistema. Degradacija ali razvrednotenje urbanega območja je proces zmanjševanja vrednosti zemljišča, stavb in naprav na njem od višjega k nižjemu stanju uporabnosti. To vodi do slabše izrabe urbanega območja ali popolne opustitve rabe. Skrajna stopnja razvrednotenja je stanje, ko na določeni lokaciji ni več mogoče vzpostaviti nobene ponovne rabe brez celovite sanacije oziroma rekonstrukcije območja. O degradaciji urbanega območja lahko govorimo tudi tedaj, ko obstoječa raba ni v skladu s pričakovano oziroma optimalno rabo - ocena degradacije torej izhaja iz ocene neizkoriščenih razvojnih potencialov oziroma primerjalnih prednosti določenega območja. Koželj (1998) navaja, da je povprečno $15 \%$ površine slovenskih mest degradiranih območij.

Degradirana urbana območja v slovenskih mestih so predvsem rezultat njihove stalne gospodarske, socialne, prometne in prostorske preobrazbe. V Ljubljani se je obseg degradiranih urbanih območij v obliki opuščenih industrijskih območij še zlasti povečal zaradi procesa deindustrijalizacije in selitve starejše industrije v industrijske cone na obrobju mesta. Deloma so degradirana urbana območja v Ljubljani tudi posledica opuščanja nekaterih drugih dejavnosti (na primer vojaška območja, gramoznice) ali pa so rezultat neustreznega prostorskega planiranja (namenska raba tal ni usklajena z potrebami in interesi investitorjev), špekulativnega zadrževanja zemljišč ali neurejenih lastniških razmer (še posebno zaradi nedokončanih postopkov denacionalizacije). Za Ljubljano so tako še posebno značilni naslednji tipi degradiranih urbanih območij, kot jih je opredelil Koželj (1998, str. 29) :

1. Industrijska območja: opuščena ali neprimerno locirana industrijska in druga proizvodna območja ali stavbe, območja skladišč, gramoznice in območja zaledja železnice

2. Vojaška območja: opuščene vojašnice

3. Sive cone: prazna in nepozidana območja ali območja z neustrezno rabo kot posledica neustreznega prostorskega planiranja, špekulativnega zadrževanja zemljišč ali neurejenih lastniških razmer

4. Degradirana stanovanjska območja: stanovanjska območja z nekvalitetnim bivalnim okoljem, slabo kvaliteto stavb, neurejenimi javnimi površinami, pomanjkljivo infrastrukturno opremljenostjo in razpršeno gradnjo.

V zadnjih 10 letih je v Ljubljani prišlo do intenzivnejše sanacije, prenove in ponovne rabe degradiranih urbanih območij. Najpogosteje gre za prostorske ureditve zasebnih investitorjev, nekaj pa je tudi primerov javnih investicij. Najpogostejša oblika ponovne rabe degradiranih urbanih območij so stanovanjska območja in nakupovalna središča, redkeje pa tudi nova gospodarska območja ali poslovne dejavnosti. V primeru degradiranih urbanih zemljišč gre pogosto za večje sklenjene površine, zato se gradijo zaključene stanovanjske soseske v obliki organizirane stanovanjske gradnje, večja nakupovalna središča ali poslovne cone. To je skladno z večino ciljev in usmeritev SPRS. Potrebna bi bili usklajeni in celoviti programi podpore in spodbujanja nadalje sanacije in revitalizacije degradiranih urbanih območij (subvencije, davčne olajšave, komasacija parcel, predkupna pravica, zasebno - javno partnerstvo). 
Karta 1: Degradirana urbana območja v Ljubljani, 2007 Map 1: Derelict urban areas in Ljubljana, 2007

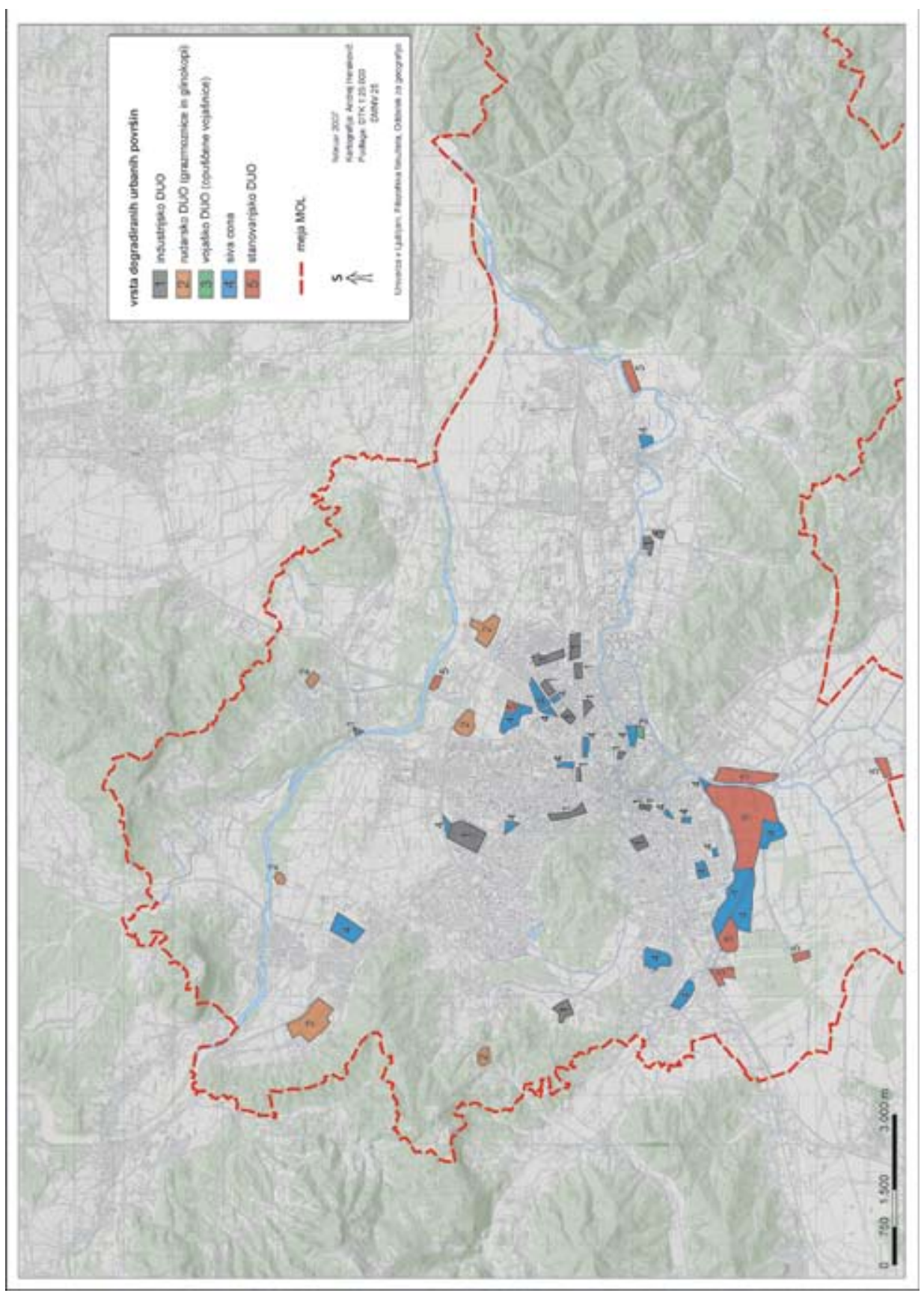


Slika 2: Degradirana urbana območja v Ljubljani-Opuščeno industrijsko območje (nekdanje mestne klavnice na Poljanski cesti)

Figure 2: Derelict urban areas in Ljubljana-Abandoned industrial area (former slaughter house at Poljanska cesta)

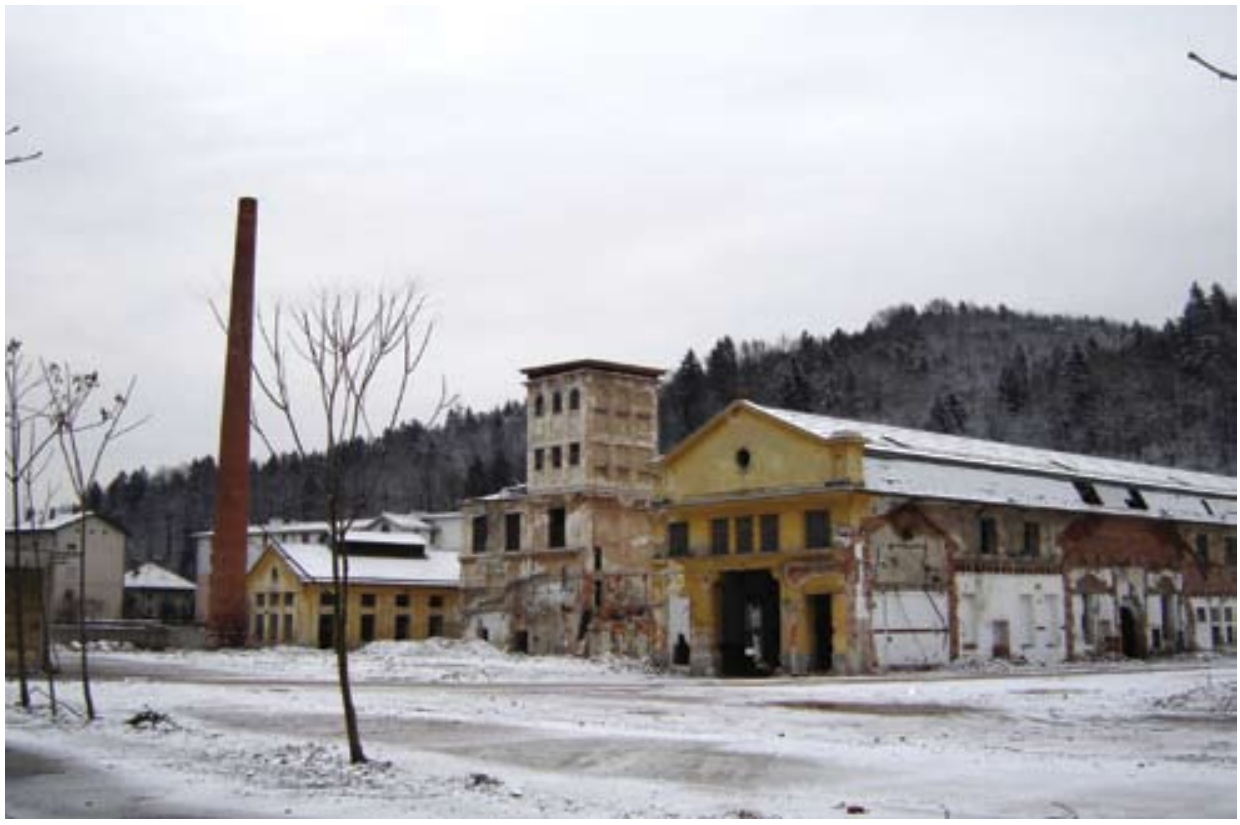

V zadnjih 10 letih je v Ljubljani prišlo do intenzivnejše sanacije, prenove in ponovne rabe degradiranih urbanih območij. Najpogosteje gre za prostorske ureditve zasebnih investitorjev, nekaj pa je tudi primerov javnih investicij. Najpogostejša oblika ponovne rabe degradiranih urbanih območij so stanovanjska območja in nakupovalna središča, redkeje pa tudi nova gospodarska območja ali poslovne dejavnosti. V primeru degradiranih urbanih zemljišč gre pogosto za večje sklenjene površine, zato se gradijo zaključene stanovanjske soseske v obliki organizirane stanovanjske gradnje, večja nakupovalna središča ali poslovne cone. To je skladno z večino ciljev in usmeritev SPRS (2004). Potrebna bi bili usklajeni in celoviti programi podpore in spodbujanja nadalje sanacije in revitalizacije degradiranih urbanih območij (subvencije, davčne olajšave, komasacija parcel, predkupna pravica, zasebno - javno partnerstvo).

V nadaljevanju navajamo nekaj najbolj obsežnih in značilnih primerov sanacije degradiranih urbanih območij v Ljubljani :

1. Opuščena industrijska območja $\rightarrow$ nakupovalno središče BTC in City Park, stanovanjska soseska Mostec, stanovanjska soseska Poljansko nabrežje, stanovanjski blok Savski kamen, stanovanjska soseska Zelena jama (ob Pokopališki cesti), stanovanjska soseska Tivoli

2. Opuščena vojaška območja $\rightarrow$ stanovanjska soseska Bežigrajski Dvor, stanovanjska soseska Nove Poljane 
Karta 2: Sanacija in ponovna raba degradiranih urbanih območij v Ljubljani Map 2: Redevelopment and new use of derelict urban areas in Ljubljana

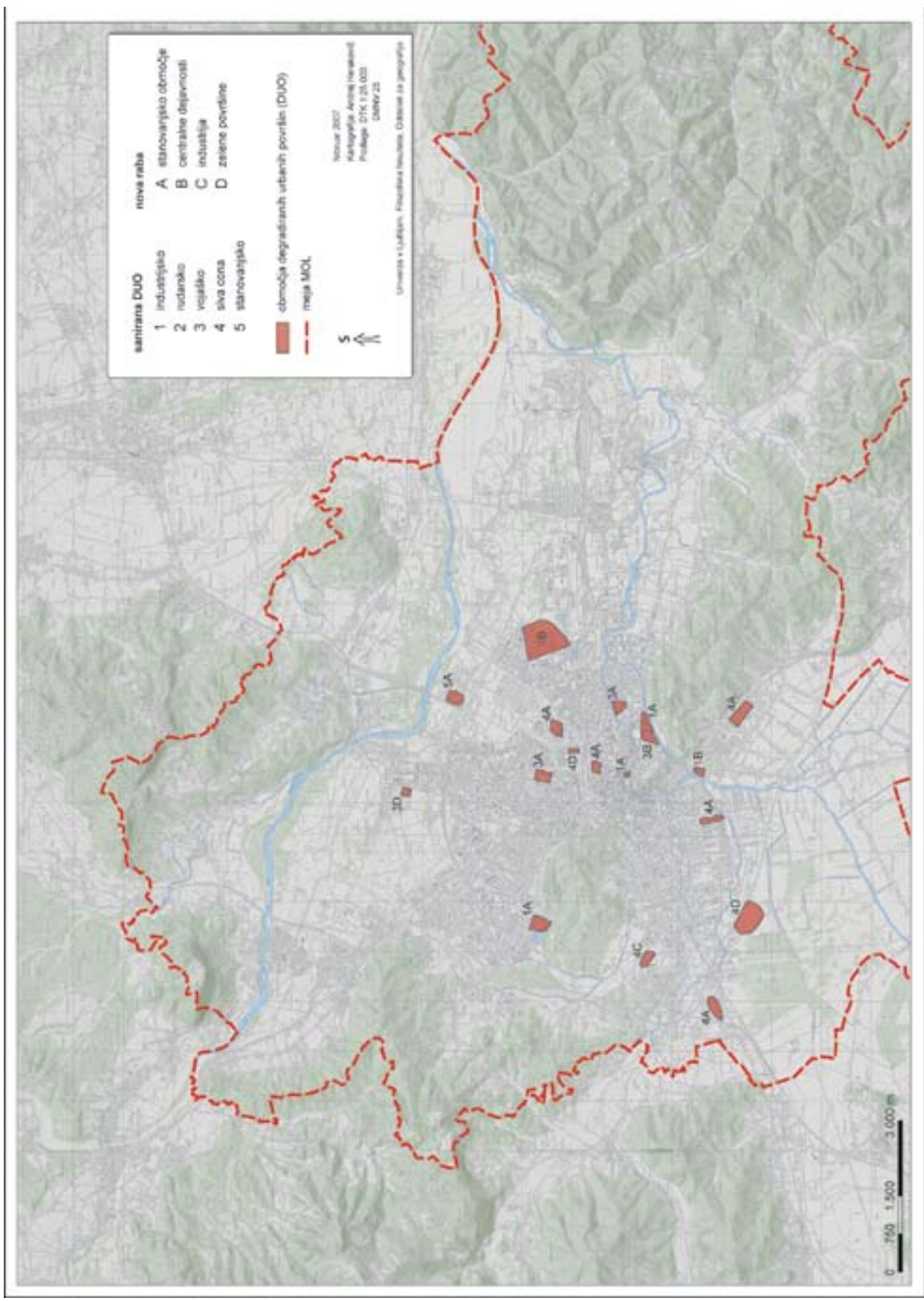


3. Sive cone $\rightarrow$ stanovanjski objekt Trubarjev kvart, stanovanjsko-poslovno območje Novi Tabor, stanovanjski blok na Glonarjevi ulici, stanovanjski blok na Bobenčkovi ulici, stanovanjska soseska Trnovska vrata, stanovanjski »vila bloki« ob Jurčkovi cesti, stanovanjski bloki ob Trnovski cesti, stanovanjski blok Antonov trg (ob Tržaški cesti), Severni park, tehnološki park Brdo

4. Degradirana stanovanjska območja $\rightarrow$ naselje vrstnih hiš Tomačevo

\subsection{Območja razpršene poselitve}

Preprečevanje nadaljnje razpršene gradnje in tudi sanacija izbranih območij razpršene poselitve je mogoča le ob dovolj veliki ponudi stavbnih zemljišč znotraj območij, za katera je izdelana urbanistična dokumentacija (občinski lokacijski načrt) in ob hkratnem doslednem preprečevanju gradnje na vseh ostalih zemljiščih - preprečevanje prakse spremembe namenske rabe zemljišč, na primer iz kmetijske v stanovanjsko, na osnovi pobud in interesov krajanov ter zasebnih investitorjev. To bi od lokalnih skupnosti zahtevalo aktivno izdelavo lokacijskih načrtov za območja stanovanjske gradnje (s primernim tipom in gostoto zazidave za posamezen tip naselja). To mora nujno spremljati tudi aktivna zemljiška politika v obliki ukrepov in inštrumentov za usmerjanje poselitve in urejanja naselij (davčni, tržni, finančni, upravni in nadzorni inštrumenti).

Tudi po letu 1991 se v Ljubljanski urbani regiji nadaljuje intenzivna suburbanizacija. Razseljevanje prebivalstva iz Ljubljane v suburbanizirano obmestje se še okrepi, saj se je v mestu Ljubljana število prebivalcev med leti 1991 in 2002 zmanjšalo za 9.000 oziroma 3.5 \%. Mestna občina Ljubljana ima negativni selitveni saldo, vse ostale občine v Ljubljanski urbani regiji so imele pozitiven migracijski saldo. Posebno velik selitveni prirast izkazujejo občine Domžale, Grosuplje, Ivančna Gorica, Medvode, Škofljica, Ig, Brezovica in Trzin. Po letu 1995 je najhitrejša rast prebivalstva značilna za manjša ruralna naselja v Ljubljanski urbani regiji. V primerjavi z obdobjem 1981 do 1991 se je torej območje naraščanja prebivalstva prostorsko razširilo iz ožjega in gosto poseljenega obmestja tudi na podeželska območja v regiji. Nova poselitev na podeželju je izrazito razpršena, pogosto izven ali na obrobju obstoječih ruralnih naselij. Pojav ima vse značilnosti procesa »urban sprawl«. Izrazit primer opisanega vzorca poselitve so podeželska območja v občinah Škofljica, Ig, Brezovica in Vrhnika. Gre izključno za novogradnje v obliki enodružinskih hiš, najpogosteje za »individualno samogradnjo«. Novogradnje se locirajo posamično ali v manjših skupinah. Kot del tega procesa je za regijo značilna tudi preobrazba naselij sekundarnih počitniških hiš v naselja s stalno naselitvijo, kot v primeru naselja Rakitna. Takšno poselitev spodbujajo pomanjkanje in visoke cene stanovanj in zazidljivih zemljišč v Ljubljani in tudi v suburbaniziranih območjih.

Območja razpršene poselitve z nizkimi gostotami prebivalstva, prevlado prostostoječih enodružinskih hiš in nizko izrabo površin so značilna tudi za posamezna območja znotraj naselja Ljubljana. Pogosto gre za stanovanjska območja črnih gradenj, ki so bila kasneje legalizirana oziroma za »urbanizirana« ruralna naselja, ki so nastala s postopno preobrazbo nekdanjih kmečkih vasi v okolici mesta. Takšna območja so se razvijala nenačrtno in brez enotne urbanistične ali morfološke zasnove. Značilno je prepletanje različnih oblik rabe tal (enodružinske stanovanjske hiše, kmetijske površine, obrtne in storitvene dejavnosti), izrazito 
Karta 3: Območja razpršsene poselitve v Ljubljani, 2007

Map 3: Areas of low-density residential areas in Ljubljana

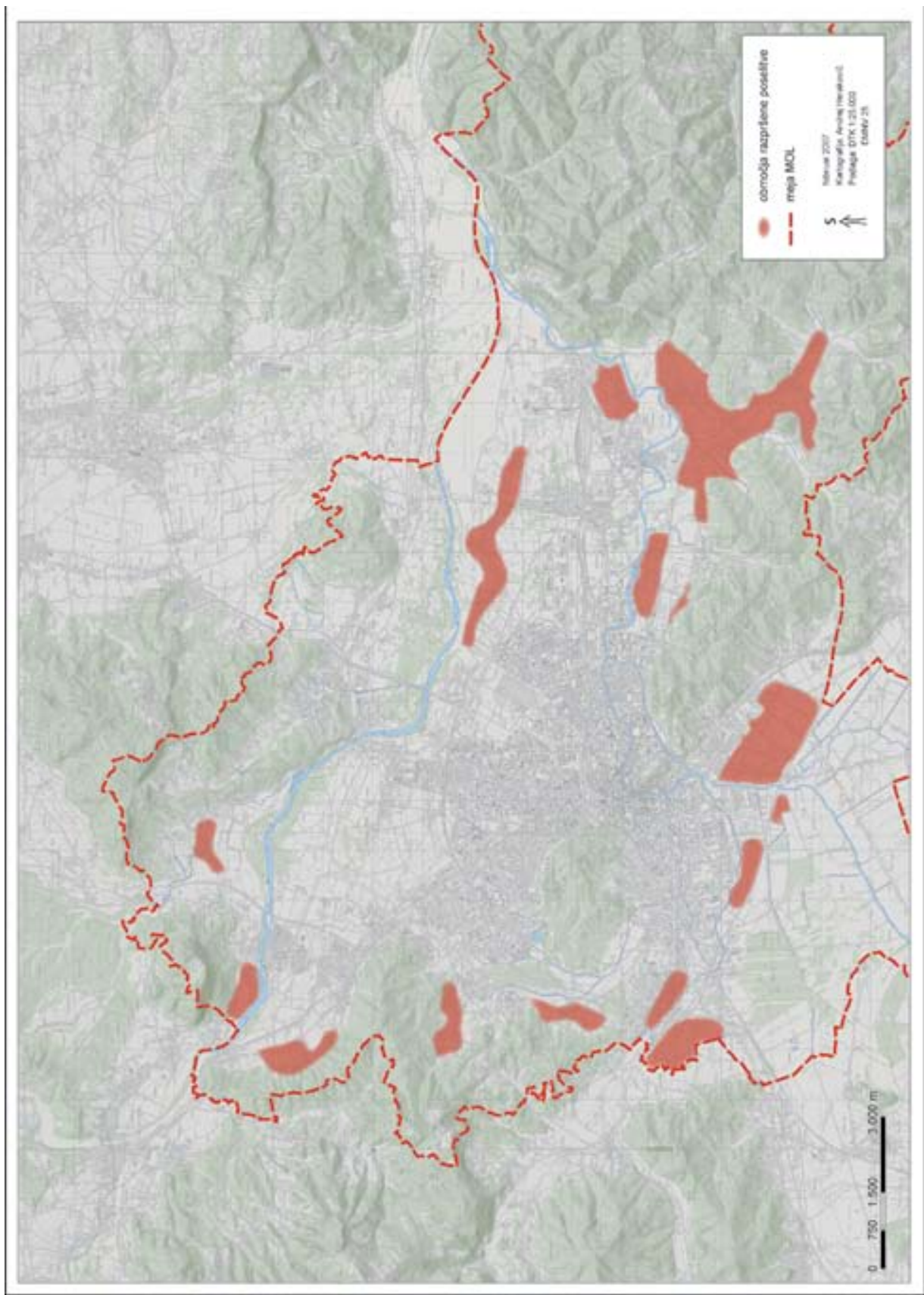


slaba komunalna in infrastrukturna opremljenost (neurejena kanalizacija, neurejene prometnice in javne površine), slaba opremljenost $\mathrm{z}$ oskrbnimi in storitvenimi dejavnosti ter praviloma tudi nekvalitetna gradnja in relativno nizek socioekonomski položaj prebivalstva. Območja razpršene gradnje ima tako določene značilnosti degradiranih stanovanjskih območij. Največja in najbolj značilna območja razpršene poselitve znotraj naselja Ljubljana so na primer mestni predeli Sibirija, Rakova Jelša, Ilovica, Galjevica, Dobrunje, Sostro, Zadvor, Spodnji Kašelj, Šmartno, Glince in Kozarje.

Slika 3: Ilovica in Galjevica: območje razpršene in nekvalitetne stanovanjske gradnje med Dolenjsko cesto in južno obvoznico

Figure 3: Ilovica and Galjevica: area of low-density and low quality housing in Ljubljana

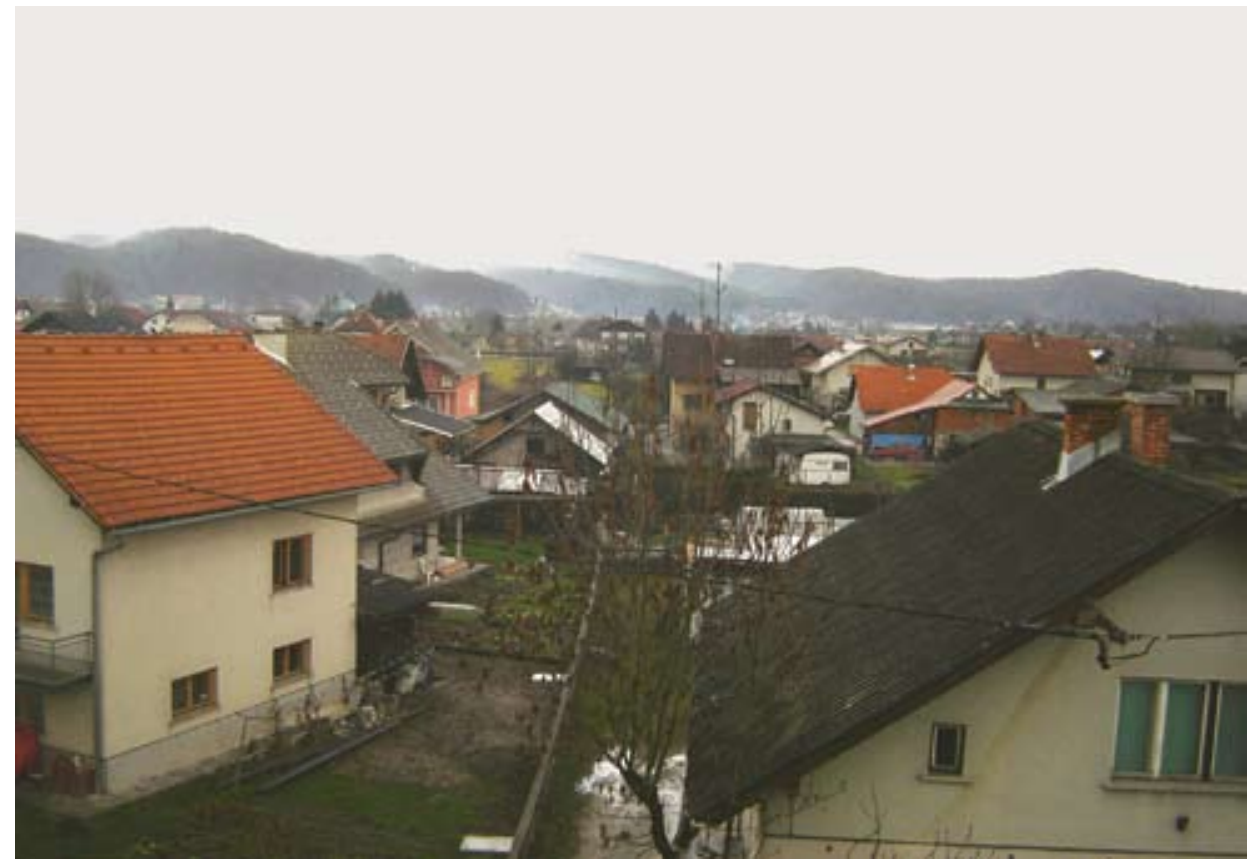

\subsection{Funkcijska preobrazba in racionalna raba zemljišč}

V pogojih tržnega gospodarstva in prevladujoče zasebne lastnine kapitala in nepremičnin dejanska raba prostora ni odvisna le od plansko določene namenske rabe prostora $\mathrm{v}$ okviru planskih kategorij (stanovanjska, proizvodnja, oskrbno-storitvena in ostala območja), temveč tudi od interesov investitorjev. V primeru zasebnih investicij do določenega posega $\mathrm{v}$ prostor pride le v primeru tržnega povpraševanja po določeni obliki rabe tal na določeni lokaciji. Ker je zelo težko napovedovati potrebe in interese investitorjev, ki se stalno spreminjajo z razvojem mesta in glede na razmere na trgu, je togo coniranje $v$ obliki strogega ločevanja namenske rabe tal v obstoječih prostorskih dokumentih pripeljalo do številnih težav v prostorskem razvoju 
slovenskih mest in drugih naselij. Na eni strani se pojavljajo številni primeri, ko v posameznih območjih ni interesa za izvedbo posega v skladu s plansko določeno namensko rabo. V tem primeru zemljišča ostajajo neizkoriščena oziroma degradirana. To lahko odvrne investitorje in pomeni resno oviro za razvoj in konkurenčnost posameznih mest in celotnih regij. Na drugi strani prihaja do pritiskov investitorjev po spremembi namenske rabe določenega zemljišča, ki pogosto pripeljejo do parcialnega spreminjanja prostorskih dokumentov in do neustreznih ter škodljivih posegov v prostor. Nova usmeritev v bolj »prožno« določevanje namenske rabe tal, zlasti v obliki »mešane rabe«, kjer je dovoljeno prepletanje funkcij in oblik rabe tal, ki se med seboj ne motijo, naj bi rešila omenjene probleme. Poleg tega naj bi imelo prepletanje funkcij in odmik od monofunkcionalnega coniranja tudi druge pozitivne učinke, zlasti zmanjševanje razdalje med lokacijo bivanja, dela in oskrbovanja in s tem do zmanjševanja prometnih tokov.

Analiza funkcijske preobrazbe Ljubljane po letu 1995 opozarja na različne procese. V funkcijski zgradbi mesta prihaja do pomembnih sprememb. Med zasebnimi investitorji je največ zanimanja za stanovanjsko gradnjo, ponekod tudi gradnjo nakupovalnih središč in poslovnih stavb. Zaradi pomanjkanja zazidljivih stavbnih zemljišč prihaja do spreminjanja namenske rabe posameznih zemljišč, ki omogočajo naštete oblike rabe tal. Poleg tega je v zadnjih dveh desetletjih prišlo do opustitve različnih oblik rabe tal, zlasti proizvodnih, skladiščnih in vojaških. Rezultat tega procesa so degradirana oziroma neustrezno izrabljena urbana območja. V odvisnosti od lokacije vlada med zasebnimi investitorji za takšna zemljišča povpraševanje zlasti za stanovanjsko gradnjo, deloma tudi za oskrbo-storitvene (nakupovalna središča) in poslovne dejavnosti. Plansko določena namenska raba v teh območjih takšne rabe tal pogosto ne dovoljuje, zato prihaja do sprememb namenske rabe. Rezultat teh procesov je vedno bolj heterogena funkcijska zgradba in mešana raba tal v številnih mestnih predelih, na kar je v svojih prispevkih opozarjal že Pak (2000, 2002). Naslednja značilnost funkcijska preobrazbe Ljubljane je nastanek velikih oskrbno-storitvenih območij, zlasti nakupovalnih središč na mestnem obrobju. Poleg trgovine so v takšnih središčih locirane tudi določene storitvene, zlasti poslovne dejavnosti. Zaradi razvoja nakupovalnih središč prihaja do nazadovanja trgovine in drugih storitvenih dejavnosti v mestnem središču in tudi v lokalnih oskrbnih središčih znotraj stanovanjskih območij. Trgovina ter storitvene in poslovne dejavnosti se v novih trgovsko-poslovnih središčih locirajo zaradi številnih prednosti in koristi: dobra dostopnost, nižje cene zemljišč, ekonomija velikosti, nižji stroški poslovanja in podobno. Prihaja torej do prostorske koncentracije in ločevanja posameznih mestnih funkcij, kar je v nasprotju z želenim prepletanjem in mešano rabo tal. Razdalje med krajem bivanja, dela in oskrbe povečujejo, kar vpliva tudi na povečevanje prometnih tokov. Hkrati potekata torej dva procesa funkcijske preobrazbe mesta: na eni strani povečevanje funkcijske heterogenosti in na drugi strani prostorska koncentracija dejavnosti.

V tem okviru se je potrebno vprašati ali je usmeritev v »prepletanje dejavnosti« in plansko »zapovedovanje « mešane rabe tal smiselno oziroma ali bo prineslo le dodatne probleme. $\mathrm{Na}$ morebitne probleme in neskladje med planskimi usmeritvami in interesi trga ter investitorjev opozarjajo številne novozgrajene poslovno-stanovanjske stavbe, v katerih poslovni prostori pogosto ostajajo neprodani in neizkoriščeni. Urbanistični akti investitorju predpisujejo mešano rabo tal s kombinacijo stanovanj in oskrbnih in poslovnih dejavnosti, čeprav na določeni 
lokaciji za poslovne prostore ni povpraševanja. Nadaljnji problem koncepta mešane rabe tal je ohranjaje kvalitete bivalnega okolja in nemoteče prepletanje dejavnosti. Najvišja kvaliteta bivalnega okolja se nedvomno ustvari v »čistih" stanovanjskih območjih. Stanovanjske soseske z najvišjo kvaliteto bivalnega okolja in najugodnejšim socioekonomskim položajem prebivalcev v Ljubljani so »čiste« stanovanjske soseske. V takšnih stanovanjskih soseskah je možno doseči manj tranzitnega prometa, manj okoljskih obremenitev (hrup, onesnažen zrak...), večjo varnost, večjo identifikacijo in skrb stanovalcev za svoje bivalno okolje, večjo urejenost in čistočo, manj konfliktov med lokalnim prebivalstvom, ne-stanovanjskimi dejavnostmi in njihovimi uporabniki in podobno.

Slika 4: Poslovno - stanovanjska zgradba Trnovska vrata z nedokončanimi pritličnimi poslovni prostori

Figure 4: Business and apartment building “Trnovska vrata” with unfinished ground floor business premises

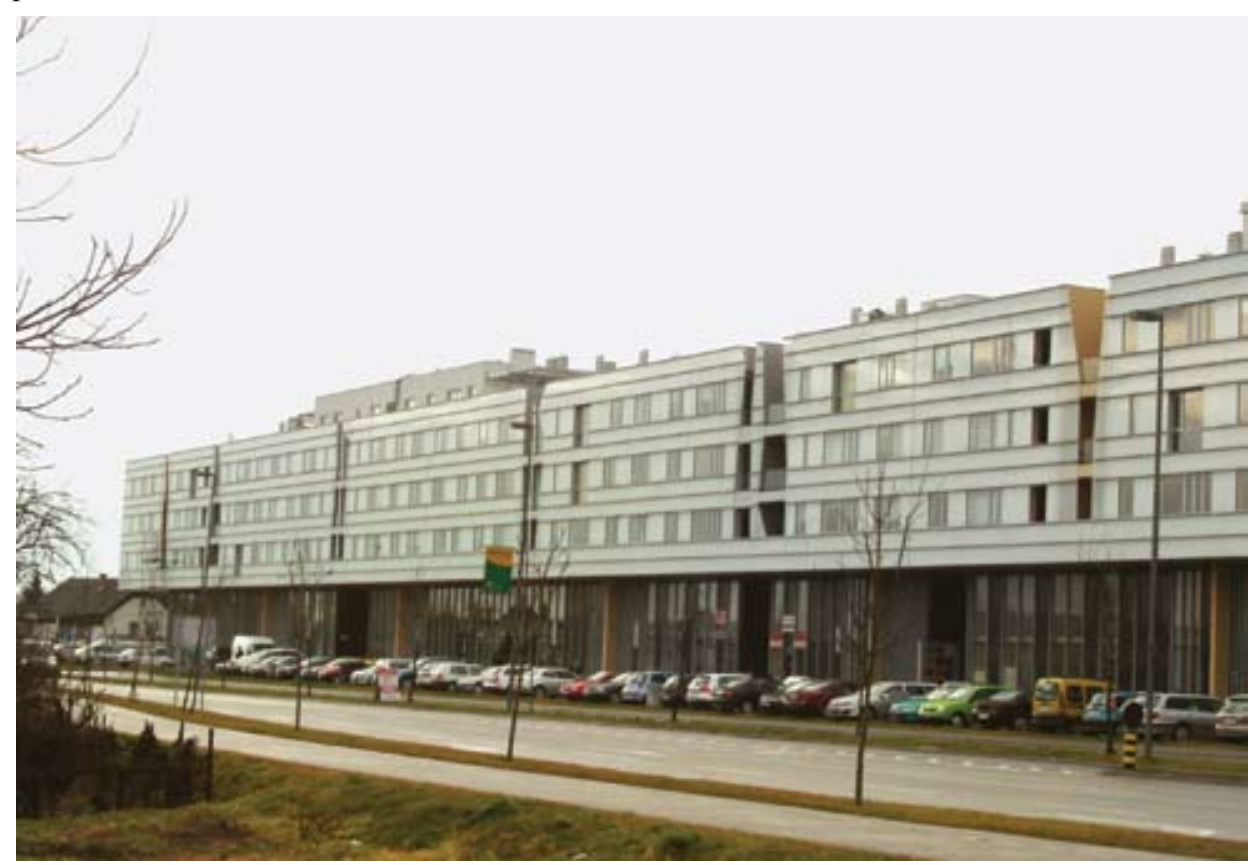

\subsection{Stanovanjska območja}

Zaradi rasti življenjskega standarda in še vedno relativno nizke stanovanjske površine na osebo (po oceni v Prostorski zasnovi MOL $23.5 \mathrm{~m}^{2}$ ), še zlasti v določenih značilnih delih mesta (blokovske stanovanjske soseske) in pri določenih skupinah prebivalstva (mlade družine) ter sprememb v strukturi gospodinjstev je kljub upadanju števila prebivalstva $\mathrm{v}$ Ljubljani pričakovati nadaljnjo veliko povpraševanje po novih stanovanjih. Povprečno število 
oseb na stanovanje se je v Ljubljani od 3.3 leta 1971 zmanjšalo na 2.4 leta 2002 (Prostorska zasnova Mestne občine Ljubljana, 2001, str. 97). Ocenjuje se, da bo v Ljubljani do leta 2015 potrebnih 15.000 novih stanovanj, 4000 zaradi dotrajanosti obstoječih stanovanj, 4000 zaradi povečanja števila gospodinjstev in 7000 zaradi porasta bivanjskega standarda (Prostorska zasnova Mestne občine Ljubljana, 2001, str. 43). Najnovejši trendi v stanovanjski gradnji kažejo na dva prostorska vzorca: nadaljevanje individualne razpršene gradnje v obmestnih in urbaniziranih podeželskih naseljih $\mathrm{v}$ Ljubljanski urbani regiji, $\mathrm{z}$ nizkimi gostotami in prevlado predimenzioniranih enodružinskih hiš ter večstanovanjska gradnja znotraj mesta, najpogosteje v obliki manjših večstanovanjskih hiš (»vila blok«). Stanovanjska gradnja V Ljubljani se je v zadnjih 10 letih postopoma povečala. Leta 1995 je bilo tako na območju Mestne občine Ljubljana zgrajenih 282 novih stanovanj (od tega 44 \% s strani pravnih oseb), po letu 2000 pa se število dokončanih stanovanj giblje med 900 in 1300, od tega okoli $75 \%$ s strani pravnih oseb (Statistični letopis Ljubljane, 2006, str. 96). Zaradi pomanjkanja večjih sklenjenih kompleksov stavbnih zemljišč so značilne zlasti posamezne večstanovanjske hiše (ali manjše skupine večstanovanjskih hiš), ki so pogosto locirane znotraj sosesk enodružinskih hiš, s čimer se spreminja obstoječa morfološka zgradba stanovanjskih območij. Zaradi ekonomskega interesa investitorjev je značilen (pre)velik izkoristek parcele, ki poslabšuje kvaliteto bivalnega okolja v posameznih stanovanjskih soseskah.

\section{Slika 5: Primer organizirane večstanovanjske gradnje v Ljubljani - soseska Nova Grbina}

Figure 5: An example of large scale housing development in Ljubljana - neighbourhood "Nova Grbina"

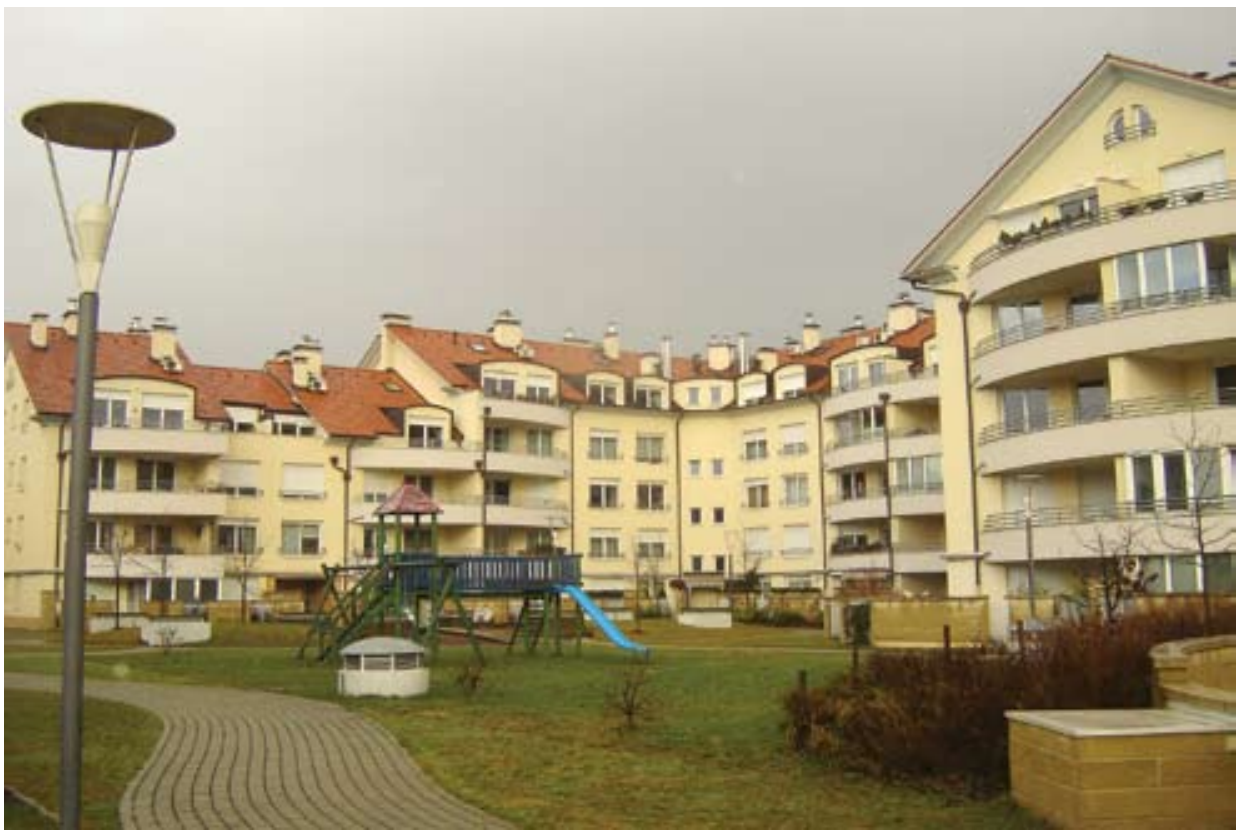


Karta 4 : Območja in tipi stanovanjske gradnje v Ljubljani po letu 2000 Map 4: Areas and types of housing development in Ljubljana after 2000

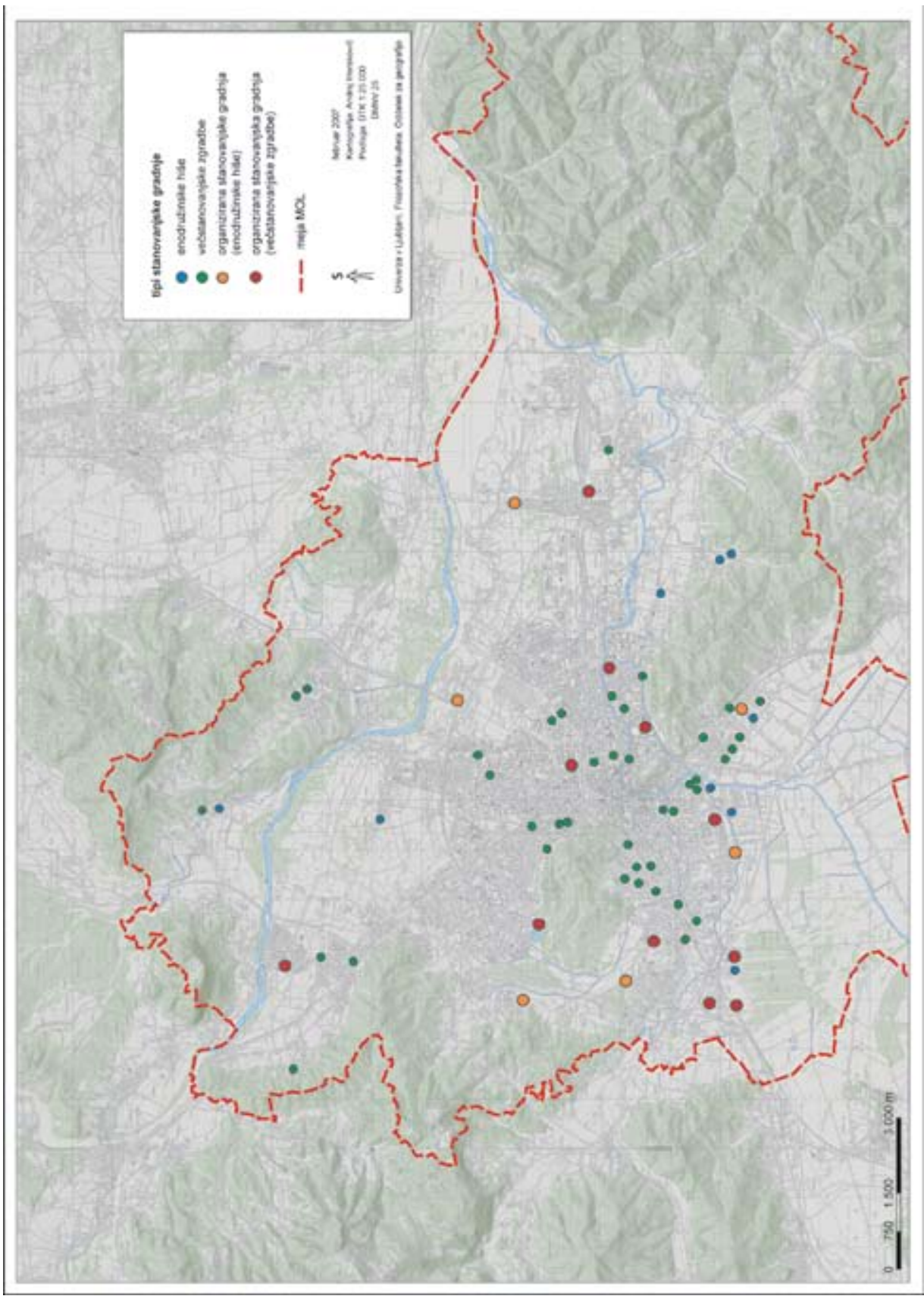




\section{ZAKLJUČEK}

Na osnovi analize stanja ter novejših trendov in procesov v prostorskem razvoju Ljubljane lahko ugotovimo, da je v prostorskem razvoju Ljubljane v zadnjih desetih letih v primerjavi s prejšnjimi obdobji, prišlo do precejšnih sprememb. Zlasti je opazen intenzivnejši »notranji razvoj« mesta ter sanacija in ponovna raba določenih degradiranih urbanih območij. Prihaja torej do zgoščevanja mesta, kar je v skladu z osnovnim usmeritvami in cilji prostorskega razvoja mest v Sloveniji. Toda ta notranji razvoj je v celoti prepuščen zasebni iniciativi, v prvi vrsti interesu po čim večjem ekonomskem donosu, kar pogosto vodi do neusklajenih in neprimernih posegov v prostor, ki poslabšujejo kvaliteto bivalnega okolja in povzročajo pre(velike) obremenitve okolja in prometnega omrežja. Ob tem so v mestu še vedno prisotna številna degradirana urbana območja in območja razpršene in gradnje, v katerih bo potrebna nadaljnja sanacija in zgoščevanje. Hkrati se nadaljuje tudi gradnja v območjih razpršene poselitve v širšem mestnem območju. V funkcijski preobrazbi mesta potekata dva nasprotujoča si procesa : na eni strani povečevanje funkcijske heterogenosti v številnih delih mesta, na drugi strani prostorska koncentracija nekaterih dejavnosti (predvsem trgovina). V mestnem središču in v lokalnih oskrbnih središčih prihaja do zamiranja trgovine na račun razvoja predmestnih nakupovalnih središč. Soočenje najnovejših trendov in procesov v prostorskem razvoju mesta ter usmeritev in ciljev trajnostnega prostorskega razvoja torej kaže na določene pozitivne razvojne težnje, ob sočasnem nadaljevanju (ne)trajnostnih oblik in vzorcev prostorskega razvoja.

\section{Viri in literatura}

Environmental policies for cities in the 90s. OECD. Paris.

ESDP. European Spatial Development Perspectives, 1999. European Commission.

Koželj, J., 1998. Degradirana urbana območja, Ministrstvo za okolje in prostor, Urad za prostorsko planiranje.

Krevs, M., 2004. Spreminjanje urbane rabe tal v Ljubljani. Dela 24. 55 - 66.

Pacione, M., 2001. Urban Geography - a Global Perspective. Routledge. London.

Pak, M., 2000. Funkcijska zgradba. Ljubljana - geografija mesta. Ljubljansko geografsko društvo. $53-58$.

Pak, M., 2002. Funkcijska zgradba Ljubljane. Geografija Ljubljane, Oddelek za geografijo, Filozofska fakulteta Univerze v Ljubljani. 131 - 148.

Pak, M., 2004. Specifični elementi v funkcijski zgradbi Ljubljane. Dela 24. 27 - 38.

Petršin V., 2000. Evropske transformacije med virtualnim in realnim. Urbani izziv 11/1. str. 43 $-49$.

Plut, D. , 2006. Mesta in sonaravni razvoj. Znanstvenoraziskovalni inštitut Filozofske fakultete.

Pogačnik, A., 2000. Urejanje prostora za tretje tisočletje. Študentska založba, Ljubljana.

Prostorska zasnova Mestne občine Ljubljana, 2002. Mestna občina Ljubljana. Oddelek za urbanizem.

Rebernik, D., Jakovčić, M., 2006. Development of retail and shopping centres in Ljubljana, Dela 26. 5-26. 
Statistični letopis Ljubljane 2006, 2006, Mestna občina Ljubljana, Služba za mestno statistiko in analize.

Strategija prostorskega razvoja Slovenije - obrazložitev in utemeljitev, 2004. Ministrstvo za okolje, prostor in energijo.

Strategija prostorskega razvoja Slovenije, 2004. Ministrstvo za okolje, prostor in energijo. Uredba o prostorskem redu Slovenije, Uradni list RS, št.

Vega, E., 2006. Ljubljana je bogatejša za nekaj tisoč stanovanj. Ljubljana - Glasilo Mestne občine Ljubljana, letnik XI. 23 - 41.

\title{
SUSTAINABLE SPATIAL DEVELOPMENT AND NEW TRENDS IN URBAN DEVELOPMENT OF LJUBLJANA
}

\begin{abstract}
Summary
The main goal of the paper is to identify, analyse and evaluate the basic processes in spatial development in Ljubljana. In the first part of the paper the main theoretical and planning concepts of sustainable urban development will be presented. Goals and aims of Slovene spatial policy regarding urban development, in particularly Strategy of Spatial Development of Slovenia and Urban Development Concept of Municipality of Ljubljana are presented as well. In the central part of the paper characteristics, trends and recent processes in urban development of Ljubljana will be presented and put into legal, social and economic framework. Spatial development of Ljubljana will be evaluated from the viewpoint of sustainable urban development. Characteristics and processes of recent urban development of Ljubljana are presented in five themes: inner urban development, derelict urban areas, areas of dispersed urbanisation, functional transformation and mixed urban land use and residential areas.

On the basis of analysis of recent studies, statistical data and fieldwork we can conclude that significant changes in urban development patterns can be observed in Ljubljana. In the first place, more intensive "inner" urban development and revitalisation of derelict urban areas can be observed. The process of densification of urban structure and intensification of land use is in accordance with goals and aims of urban policy in Slovenia and Ljubljana. But this inner development is entirely directed by private investors and their interests, which results in frequent inadequate or impropriate developments, causing further degradation of urban and living environment. With urban sprawl characterising rural parts of the region, several areas of dispersed urban development with low densities, unplanned land use patterns and low quality of housing and living environment can be found in the city of Ljubljana as well. Functional transformation revels two parallel processes: increasing functional heterogeneity with mixed land use and spatial concentration of several activities, mostly retail and services, in suburban shopping and business centres. This is accompanied by gradual decline of retail in central and local business centres. The confrontation of recent processes in urban development of Ljubljana and goals and aims of sustainable urban development thus reveals some positive development trends as well as continuation of non-sustainable patterns in urban development.
\end{abstract}

